\title{
Elevated Serum Levels of the Decoy Receptor Osteoprotegerin in Children with Langerhans Cell Histiocytosis
}

\author{
DIEGO A. ROSSO, JENNY KARIS, JORGE L. BRAIER, JAN-INGE HENTER, AND BENGT FADEEL
}

\begin{abstract}
Division of Molecular Toxicology [B.F., J.K.], Institute of Environmental Medicine, Karolinska Institutet, 17177 Stockholm, Sweden; Department of Woman and Child Health [J.K., J.I.H.], Childhood Cancer Research Unit, Karolinska University Hospital, 17176 Stockholm, Sweden; Department of Hematology-Oncology [D.A.R., J.L.B.], Hospital Juan P. Garrahan, 1245 Buenos Aires, Argentina; Department of Pediatrics [D.A.R.], Hospital de Clínicas, 1120 Buenos Aires, Argentina; Department of Pharmacology [D.A.R.],
\end{abstract} Universidad de Buenos Aires, 1121 Buenos Aires, Argentina

\begin{abstract}
Langerhans cell histiocytosis ( $\mathrm{LCH})$ is characterized by an accumulation of dendritic Langerhans cells in granulomatous lesions in the bone, skin, and other sites in the body. The pathogenesis of the disease remains unknown. We measured serum levels of the decoy receptor osteoprotegerin (OPG), an important regulator of bone metabolism as well as immune responses, in 18 children with single system (SS) or multi-system (MS) forms of LCH and 20 pediatric controls. OPG levels were significantly increased in $\mathrm{LCH}$ patients at diagnosis when compared with controls, and pretreatment levels of OPG were elevated in MS compared with SS patients. Moreover, OPG levels in $\mathrm{LCH}$ patients were elevated in patients with involvement of risk organs (liver, lungs, hematopoietic system, or spleen) when compared with patients without risk organ involvement, indicative of an association between OPG values and disease severity. We also observed a positive correlation between serum levels of OPG and tumor necrosis factor (TNF)- $\alpha$, a proinflammatory cytokine, at the time of onset of disease. These findings show, for the first time, that serum OPG levels are elevated in $\mathrm{LCH}$ patients, and suggest that OPG may play a role in the pathogenesis of this enigmatic disease. (Pediatr Res 59: 281-286, 2006)
\end{abstract}

$\mathrm{L}$ angerhans cell histiocytosis (LCH) affects mainly young children and features an accumulation of $\mathrm{CD} \mathrm{a}^{+}$dendritic Langerhans cells (LCs) in the skin, bone, and occasionally other organs, including lymphoid tissues, lungs, and digestive tract (1). Clinically, LCH ranges from self-healing lesions to a multi-system involvement with organ dysfunction resistant to current therapies (2). Previous studies have shown that LCs from bone lesions and/or chronic forms of the disease are functionally immature, whereas LCs in patients with selfhealing or isolated cutaneous disease possess a more mature phenotype (3). Nevertheless, the etiology of $\mathrm{LCH}$ remains unknown, and it is even debated whether LCH is a reactive

\footnotetext{
Received February 14, 2005; accepted August 22, 2005.

Correspondence: Bengt Fadeel, M.D., Ph.D., Division of Molecular Toxicology, Institute of Environmental Medicine, Nobels väg 13, Karolinska Institutet, 17177 Stockholm, Sweden; e-mail: bengt.fadeel@ki.se.

Supported by the Asociación Argentina de Padres de Niños con Histiocitosis, the Cancer and Allergy Foundation of Sweden, the Märta and Gunnar Philipson Foundation, the Jeansson Foundation, the Swedish Children's Cancer Foundation, the Swedish Cancer Foundation, and the Swedish Research Council.

D.A.R. and J.K. contributed equally to this work.

DOI: 10.1203/01.pdr.0000196375.47889.5b
}

condition, linked to an abnormal response of LCs and other immune cells to offending pathogens, or a neoplastic disease $(4,5)$.

Abundant levels of tumor necrosis factor (TNF)- $\alpha$ and other pro-inflammatory cytokines, and the co-stimulatory molecules CD40 and CD40 ligand (CD40L), are seen in LCH lesions (6-8) thus creating a veritable "cytokine storm" that may account for many of the systemic symptoms in these patients, as well as some of the long-term sequelae (pulmonary abnormalities, CNS dysfunction, etc) $(9,10)$. Moreover, our recent studies have revealed elevated levels of TNF- $\alpha$ in the serum of LCH patients (11), and we have shown the addition of antiTNF- $\alpha$ treatment to conventional chemotherapy to be beneficial in a child with severe $\operatorname{LCH}(12)$.

Osteoprotegerin $(\mathrm{OPG})$ is a member of the TNF receptor superfamily, and functions as an inhibitor of bone resorption by binding to RANKL (receptor activator of NF $\kappa \mathrm{B}$ ligand), thereby blocking the interaction between RANKL and RANK (13). OPG is also a decoy receptor for TRAIL (TNF-related apoptosis-inducing ligand) (14), a pro-apoptotic factor involved in killing of cells in the immune system, including dendritic cells (DCs) (15). OPG is produced by numerous cell types, such as osteoblasts, DCs, and B cells, and its expression is up-regulated upon CD40 ligation (16). OPG is present as a secreted factor in serum, and has also recently been detected in human milk (17). Importantly, OPG has been suggested to function as a crucial regulator not only of bone metabolism, but also of B cell and DC function (18).

Previous studies have shown that serum OPG levels are reduced in multiple myeloma (MM) patients with lytic bone lesions (19); conversely, treatment of mice with established myeloma with recombinant OPG was found to prevent the development of osteolytic bone disease (20). Furthermore, recent studies have disclosed elevated serum OPG levels in rheumatoid arthritis (RA) patients (21). Interestingly, antiTNF- $\alpha$ treatment resulted in the normalization of OPG values in the latter group, thus supporting the notion that proinflammatory cytokines control the production of OPG. De-

\footnotetext{
Abbreviations: CD, Crohn's disease; DC, dendritic cell; LCH, Langerhans cell histiocytosis; MGC, multinucleated giant cell; MS, multi-system; OPG, osteoprotegerin; RA, rheumatoid arthritis; SS, single system
} 
regulated OPG levels could contribute to osteoclast activation and/or impairment of DC function in $\mathrm{LCH}$ patients. The purpose of the current study was to determine the serum levels of OPG in a well-defined cohort of $\mathrm{LCH}$ patients.

\section{METHODS}

Patients and controls. Serum samples were obtained at onset of disease from $18 \mathrm{LCH}$ patients who fulfilled the Histiocyte Society criteria for diagnosis, stratification, and treatment (2). The following clinical stages were considered: single system (SS) or multi-system (MS) disease, with or without involvement of risk organs (liver, lungs, hematopoietic system, or spleen); in addition, a comparison was made between patients who presented with or without bone involvement at the time of diagnosis (Table 1). For some cases, consecutive serum samples were analyzed, at diagnosis and/or during follow-up of treatment; a total of 50 samples from $30 \mathrm{LCH}$ patients were thus included in the study. Control samples were obtained from 20 children undergoing minor elective surgery (median age $3 \mathrm{y}$; range 1-13). The study protocol was approved by the ethical committee of the Hospital Garrahan in Buenos Aires and Karolinska Institutet in Stockholm. Informed parental consent was obtained in all cases.

Cytokine measurements. Concentrations of OPG were measured by a sandwich ELISA using a set of specific antibodies and recombinant human OPG standard from R\&D Systems (Minneapolis, MN), according to the manufacturer's instructions. The performance range was $62.5-4000 \mathrm{pg} / \mathrm{mL}$ and the detection limit was $30 \mathrm{pg} / \mathrm{mL}$. Serum levels of sIL-2R and IL-1Ra were estimated using commercial ELISA kits obtained from R\&D Systems, as previously described $(11,22)$. TNF- $\alpha$ concentrations were determined by chemiluminescent immunometric assay using an IMMULITE automated analyzer (Diagnostic Products, Los Angeles, CA), according to the manufacturer's instructions.

Statistical analysis. The 2-tailed Mann-Whitney $U$-test was used to compare the levels of OPG in different groups of patients and controls. Correlations between cytokine concentrations (sIL-2R, IL-1Ra, TNF- $\alpha$ ) and OPG were assessed by the Spearman rank order test. Data are reported as mean values \pm SEM or as median values and range. Results were considered statistically significant when $P$ values were $<0.05$. All calculations were performed using SPSS 11.5 software (Chicago, IL).

\section{RESULTS}

Serum levels of OPG at diagnosis. The OPG levels in our cohort of LCH patients at the time of diagnosis (i.e., before treatment $)$ were $1901 \pm 250 \mathrm{pg} / \mathrm{mL}(n=18)$ and in controls $427 \pm 41 \mathrm{pg} / \mathrm{mL}(n=20)$. OPG levels in all except two of the LCH patients were above $843 \mathrm{pg} / \mathrm{mL}$, the highest value detected in the control group, and the difference between the two groups was significant $(p<0.001)$ (Fig. 1A). Statistically significant differences were also observed between patients with SS $(n=8)$ and MS $(n=10)$ forms of the disease, when monitored at the time of diagnosis $(1266 \pm 157 \mathrm{pg} / \mathrm{mL}$ vs. $2409 \pm 363 \mathrm{pg} / \mathrm{mL} ; p=0.021$ ) (Fig. 1B). LCH patients with bone involvement at the time of diagnosis $(n=13)$ were found to have lower levels of OPG when compared with those without bone lesions $(n=5)(1727 \pm 296 \mathrm{pg} / \mathrm{mL}$ vs. $2353 \pm$ $444 \mathrm{pg} / \mathrm{mL}$ ), but this difference did not show statistical significance (Fig. 1 C). Patients with involvement of risk organs were found to have significantly higher OPG levels compared with individuals without risk organ involvement [risk organs $(n=10), 2534 \pm 308 \mathrm{pg} / \mathrm{mL}$ vs. no risk organs $(n=8), 1109$ $\pm 166 \mathrm{pg} / \mathrm{mL}$ vs.; $p=0.001$ ] (Fig. 1D). However, it should be noted that only 2 of the patients with MS disease did not have risk organ involvement at the time of diagnosis, whereas four of the eight MS patients with risk organ involvement had bone lesions; hence, the most valid comparison may be between patients with MS and SS disease, and patients with or without bone lesions, respectively.

OPG levels upon treatment. Paired samples obtained at the time of diagnosis and after initiation of treatment were available from a subset of $\mathrm{LCH}$ patients (Table 1). A decrease in serum OPG levels was seen in two of three patients who were classified as active disease better (ADB) at the time of followup, whereas in two patients considered as active disease intermediate (ADI) at follow-up (i.e., nonresponders), OPG levels were moderately increased (Fig. 2). In one child (patient nine) who displayed severe lung involvement after $6 \mathrm{wk}$ of treatment and was classified as active disease worse (ADW),

Table 1. LCH patient characteristics and serum concentrations of cytokines

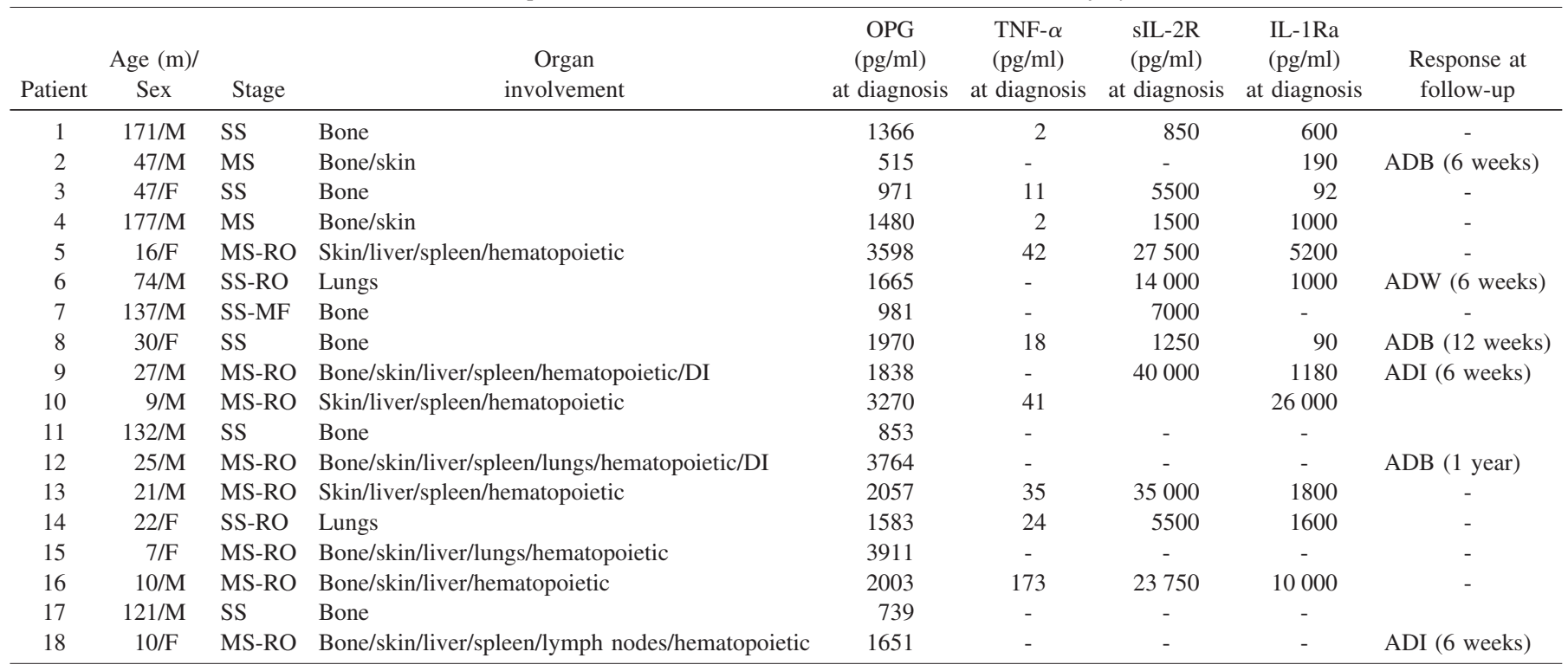

Clinical stage: SS, single system (single site); SS-MF, single system (multifocal disease); MS, multi-system without risk organ involvement; MS-RO, multi-system with risk organ involvement; DI, diabetes insipidus.

Clinical response: ADB, active disease better; ADI, active disease intermediate; ADW, active disease worse. 
A

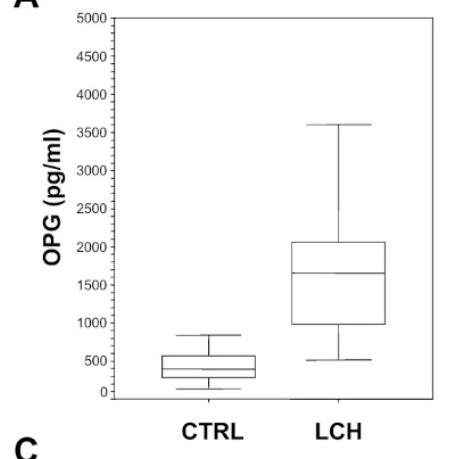

C

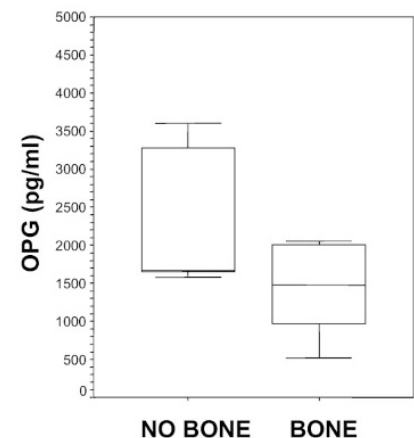

B
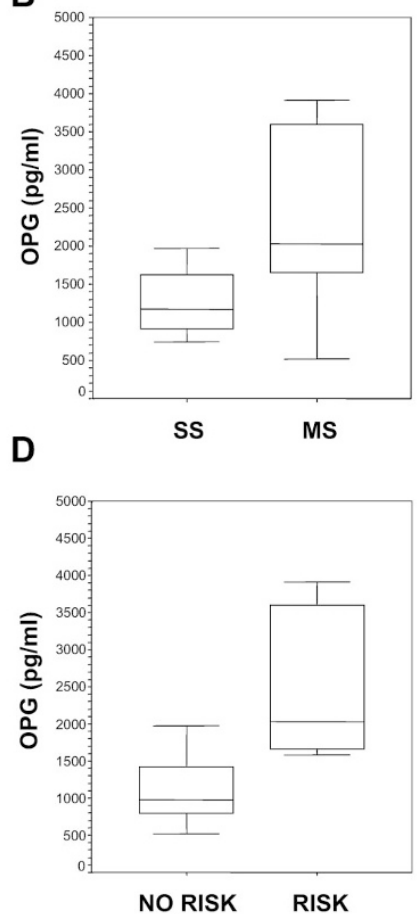

Figure 1. Elevated serum levels of OPG in LCH patients. (A) Serum OPG levels in pediatric controls (CTRL) $(n=20)$ and in LCH patients $(\mathrm{LCH})(n$ $=18$ ), as determined by ELISA. The median value in patients was 1658 $\mathrm{pg} / \mathrm{mL}$ (range 515-3911) and $396 \mathrm{pg} / \mathrm{mL}$ (range 133-843) in controls $(p<$ $0.001)$. (B) OPG values in LCH patients with single system $(\mathrm{SS})(n=8)$ and multi-system (MS) $(n=10)$ forms of the disease. Median values were 1173 and $2030 \mathrm{pg} / \mathrm{mL}$, respectively $(p=0.021)$. C) OPG values in LCH patients grouped according to whether bone involvement was present $(n=13)$ or absent $(n=5)$ at the time of diagnosis (BONE vs. NO BONE). Median values were 1480 and 1655 , respectively $(p=0.301)$. D) OPG values in LCH patients displaying no risk organ involvement (NO RISK) $(n=8) v s$ involvement of risk organs (RISK) $(n=10)$ at the time of diagnosis (median values 976 and $2030 \mathrm{pg} / \mathrm{mL}$, respectively) $(p=0.001)$. Boxes $(\mathrm{A}-\mathrm{D})=25^{\text {th }}$ and $75^{\text {th }}$ percentiles; horizontal lines within boxes $=$ median values; vertical bars below and above boxes $=$ range.

the serum level of OPG was significantly increased (Fig. 2). Additional, consecutive serum samples were available from 2 of these children. For patient 12, who improved upon treatment, OPG levels were initially reduced from 3764 to 1566 $\mathrm{pg} / \mathrm{mL}$. This patient was also assessed 2 y after diagnosis, following continued clinical improvement, at which time OPG levels had decreased further to $600 \mathrm{pg} / \mathrm{mL}$. OPG levels in patient 18 , who presented with MS disease, were assessed on six occasions and decreased gradually from 1651 to 679 $\mathrm{pg} / \mathrm{mL}$ during the course of treatment; this child exhibited signs of progressive disease yet responded well to a combination of chemotherapeutic drugs and anti-TNF- $\alpha$ treatment (etanercept) and was classified as having nonactive disease (NAD) 2 y after diagnosis. Of note, the evolution of bone lesions in patient 12 (middle ear bone involvement, and osteolytic lesions of the skull and left femur) and patient 18 (middle ear bone involvement only) during the course of treatment was favorable in both cases.

Other markers of inflammation. We have previously shown that pretreatment serum levels of soluble IL-2 receptor (sIL-2R), IL-1 receptor antagonist (IL-1Ra), and TNF- $\alpha$ are

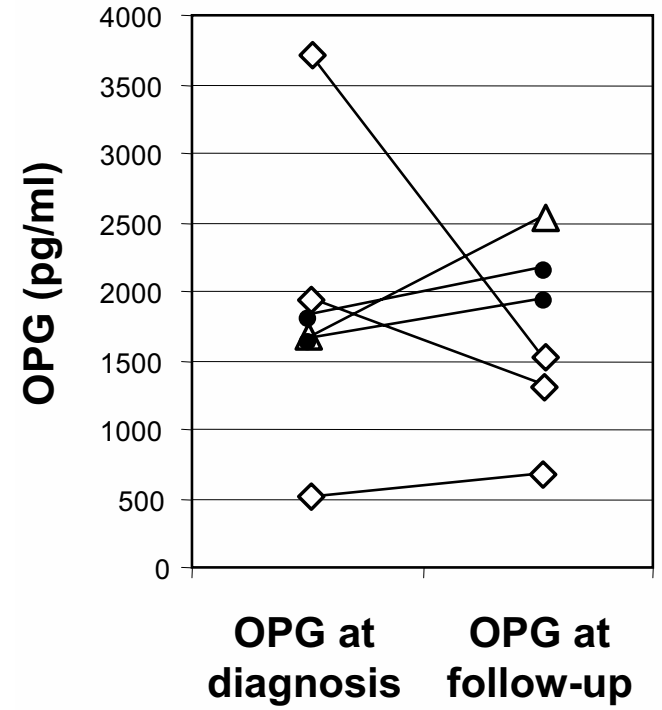

Figure 2. Serum levels of OPG upon treatment of LCH patients. The graph represents OPG values at the time of diagnosis and at follow-up in six LCH patients (consult Table 1 for details). Patients classified as ADB (active disease better, $\diamond)$ at the time of follow-up were considered to be responders, whereas patients classified as ADI (active disease intermediate, $\bullet$ ) or ADW (active disease worse, $\triangle$ ) were considered to be nonresponders. For comparison, the median value of OPG in pediatric controls was $396 \mathrm{pg} / \mathrm{mL}$ (range 133-843) $(n=20)$ (Fig. 1).

elevated in children with LCH $(11,22)$. In the present study, we analyzed serum levels of these cytokines in LCH patients at the time of diagnosis [TNF- $\alpha(n=9)$, sIL-2R $(n=12)$, $\operatorname{IL}-1 \mathrm{Ra}(n=11)]$ as well as in pediatric controls $(n=14$ for TNF- $\alpha$ and sIL-2R measurements, and $n=7$ for IL-Ra measurements). All three cytokines were significantly elevated in LCH patients when compared with controls, in line with our previous observations (Table 2). Furthermore, in a subset of LCH patients $(n=8)$ for whom serum concentrations of the three cytokines as well as OPG were available at the onset of disease (Table 1), a significant positive correlation was observed between OPG and TNF- $\alpha(r=0.826 ; p=$ 0.011). In addition, a similar trend was observed when sIL-2R

Table 2. Serum concentrations of cytokines in LCH patients and controls

\begin{tabular}{lccc}
\hline & LCH patients* & Controls & P values $\$$ \\
\hline TNF- $\alpha$ & $24(2-173)$ & $7.5(2-10)$ & 0.016 \\
SIL-2R & $10500(850-40000)$ & $610(343-800)$ & 0.0001 \\
IL-1Ra & $1000(90-10000)$ & $190(47-420)$ & 0.0268 \\
OPG $\dagger$ & $1658(515-3911)$ & $396(133-843)$ & 0.001 \\
\hline
\end{tabular}

* Data are reported as median (range); all concentrations are shown as $\mathrm{pg} / \mathrm{ml}$.

For the purpose of analysis, for cytokine concentrations below the detection limit of the assay, a value halfway between zero and the lower limit of detection was used.

$\dagger$ OPG values are identical to those reported in Figure 1, and are included here for comparison ( $n=18$ and 20, for patients and controls, respectively).

$\$$ The non-parametric Mann-Whitney test was used to determine differences between patients and controls [TNF- $\alpha: n=9$ (patients) and $n=14$ (controls); sIL-2R: $n=12$ (patients) and $n=14$ (controls); IL-1Ra: $n=11$ (patients) and $n=7$ (controls)]. 
and IL-1Ra values were compared with TNF- $\alpha$ values in this cohort of LCH patients $(r=0.795 ; p=0.018$, and $r=0.778$; $p=0.023$, respectively).

\section{DISCUSSION}

OPG is a secreted protein that regulates bone metabolism as well as immune responses. In the present study, we show that serum concentrations of OPG are significantly elevated in $\mathrm{LCH}$ patients at the time of diagnosis, when compared with pediatric controls. Moreover, OPG levels in $\mathrm{LCH}$ patients were found to correlate with serum levels of TNF- $\alpha$, an important pro-inflammatory cytokine. In a subset of patients, OPG levels were shown to decrease upon treatment; however, the latter data should be interpreted with caution due to the small number of patients included in the follow-up analysis. Nevertheless, these results indicate, for the first time, that serum levels of the decoy receptor OPG are elevated in $\mathrm{LCH}$, and provide evidence of a correlation between OPG levels and other markers of inflammation.

LCH lesions feature both osteoclast-like multinucleated giant cells (MGCs) and antigen-presenting LCs (4). A very recent immunohistochemical study suggested that the cytokine environment in these lesions may allow local formation rather than attraction of osteoclast-like MGCs; such cells could, in turn, contribute to the tissue destruction seen in $\mathrm{LCH}$ patients (23). Hence, these investigators were able to demonstrate the expression of two OPG-interacting molecules, RANK and RANKL, in bone and nonbone lesions in $\mathrm{LCH}$ patients. OPG expression was not determined. Nevertheless, based on these findings, MGCs and osteoclast-inducing cytokines were suggested to be suitable as a potential target for the treatment of LCH. Indeed, we and others have recently shown that various osteoclastogenic factors are highly expressed in the serum and/or in lesions in $\mathrm{LCH}$ patients $(8,24)$. The aforementioned observations provide a rationale for the use of bisphosphonates (potent inhibitors of bone resorption) in $\mathrm{LCH}$ patients with osteolytic lesions and bone pain $(25,26)$. Moreover, the recent demonstration that pamidronate stimulates OPG production by human osteoblasts (27) further supports the notion that the RANKL-OPG axis may play an important role in this context. Further studies of RANK and RANKL expression, and of serum levels of OPG, in LCH patients before and after treatment with bisphosphonates are thus warranted.

Serum levels of OPG were previously shown to be decreased in MM patients with osteolytic lesions (19), and subsequent investigations showed that OPG was internalized and degraded by MM cells, thereby providing a possible explanation for the low levels of OPG in myeloma patients (28). Our current results indicate that $\mathrm{LCH}$ patients with bone lesions have lower serum levels of OPG when compared with patients without bone lesions; however, overall, LCH patients were found to have elevated serum concentrations of OPG in comparison to pediatric controls. At first glance, increased levels of the decoy receptor OPG in patients with bone lesions argues against a role for the RANKL-OPG system in the development of bone loss in LCH. However, increased OPG levels could also represent a continuing homeostatic response, attempting to reverse established osteopenia and RANKLdriven osteoclastogenesis, thus maintaining normal bone mass. In support of this contention, recent studies of other conditions of chronic inflammation have provided further evidence of a paradoxical relation between OPG and bone lesions. For instance, in patients with Crohn's disease (CD) and ulcerative colitis, increased OPG concentrations were detected $(29,30)$. These results may appear counterintuitive since OPG interferes with osteoclast differentiation, conferring skeletal benefit, whereas inflammatory bowel disease is frequently associated with bone loss. However, up-regulation of OPG could serve as a protective host response that partially offsets the adverse skeletal effects created by the inflammatory state. Alternatively, elevated OPG in CD patients may reflect $\mathrm{T}$ cell activation (30). Compelling evidence for an important role of OPG in maintaining bone homeostasis during chronic inflammation comes from an animal model of spontaneous osteopenia and colitis (31). In this model, inhibition of RANKL-RANK interactions with exogenous recombinant OPG was shown to reverse skeletal abnormalities and reduce colitis. These findings suggest that the RANKL-OPG system may play a dual role in inflammatory bowel disease, influencing not only the bone but also gut pathology.

Numerous studies have shown that OPG has the potential to modulate osteoclast activation as well as the activation and survival of DCs $(13,32)$. Moreover, transdifferentiation of immature DCs into functional osteoclasts in the presence of RANKL was recently reported (33). Indeed, pro-inflammatory cytokines such as TNF- $\alpha$ were shown to promote cell fusion during DC transdifferentiation and lead to the formation of larger MGCs than RANKL alone. The dual role of OPG in bone homeostasis and immune modulation is thus suggestive of a dual role for OPG in the pathogenesis of LCH, insofar as OPG may affect osteoclast-like MGCs or LCs, or both. However, our results could also imply a compensatory response to enhanced osteoclast activation (34), or may be viewed as a sign of chronic immune activation, in line with previous findings in RA patients and in patients with CD $(21,29,35)$. Our current observation that OPG levels are higher in MS than in SS patients supports the latter view. Furthermore, previous results from our laboratory have suggested that elevated erythrocyte sedimentation rate (ESR) and thrombocytosis, two signs of chronic immune activation, is common in $\mathrm{LCH}$ patients with active disease (36). Interestingly, in a recent study of patients with RA, a direct correlation was seen between serum OPG and ESR and the Larsen score (a disease activity score), supporting the notion that serum OPG may be linked to, or driven by, systemic inflammation (37). We also show herein that OPG levels are elevated in patients with risk organ involvement at the time of diagnosis, suggesting that OPG levels are reflective of overall disease activity in these children. However, more patients need to be evaluated before general conclusions can be drawn concerning differences between patients with or without risk organ involvement, since there were only two patients with MS disease who had no risk organ involvement whereas four of the eight MS patients with risk organ involvement had bone lesions. 
LCH is associated with high expression of several cytokines, both in serum and in granulomatous lesions in these patients $(6,8,11,22,38)$. We have previously reported that pretreatment serum levels of TNF- $\alpha$, sIL-2R, and IL-1Ra are elevated in LCH $(11,22)$. Similarly, in the present study, these immunomodulating cytokines were highly expressed in LCH patients at the time of onset of disease; moreover, a significant positive correlation was observed between TNF- $\alpha$ and OPG serum concentrations, at the time of diagnosis. These results thus demonstrate, for the first time, a correlation between OPG values and the expression of an important pro-inflammatory cytokine (TNF- $\alpha$ ) in children with LCH. We have also recently reported that TNF- $\alpha$ is abundantly expressed in $\mathrm{CD}_{1} \mathrm{a}^{+}$ LCs in lesions from LCH patients (8). Interestingly, in the latter study, the children with the highest proportion of cells expressing TNF- $\alpha$ were shown to have risk organ involvement. Other investigators have shown that OPG expression is up-regulated by TNF- $\alpha$ in a time- and dose-dependent manner in rheumatoid synovial fibroblasts (39). Thus, although TNF- $\alpha$ is known to stimulate bone destruction, TNF- $\alpha$ induced up-regulation of OPG could perhaps contribute to self-protection from bone destruction in RA patients. Moreover, a recent study has shown that anti-TNF- $\alpha$ treatment of RA patients resulted in a normalization of serum OPG levels (21). Successful treatment of LCH with etanercept, a soluble receptor fusion protein that functions as a TNF- $\alpha$ antagonist, has been reported in a limited number of cases to date (12; the present study), and the usefulness of this novel treatment has been called into question by other investigators (4); nevertheless, it would be of considerable interest to determine serum levels of OPG in LCH patients before and after treatment with anti-TNF- $\alpha$ agents, to assess whether OPG levels are regulated by TNF- $\alpha$ in these children.

In conclusion, our investigations are the first to show that serum levels of OPG are elevated in LCH. We also show that other serum markers of inflammation, including TNF- $\alpha$, are elevated in these patients, and a correlation between serum OPG and TNF- $\alpha$ was observed. Larger series of patient sera should be evaluated for OPG expression to extend these results. Furthermore, although an involvement of the RANKL-OPG system in the development of bone lesions in LCH patients cannot be excluded, we favor the view that elevated OPG is a sign of inflammation and perhaps reflective of disease activity in these children. Further studies of OPG and OPG-interacting molecules (40) may yield novel targets for the treatment of $\mathrm{LCH}$, and may also provide additional insights into DC biology.

\section{REFERENCES}

1. Arceci RJ 1999 The histiocytoses: the fall of the Tower of Babel. Eur J Cancer 35:747-767

2. Gadner H, Grois N, Arico M, Broadbent V, Ceci A, Jakobson A, Komp D, Michaelis J, Nicholson S, Potschger U, Pritchard J, Ladisch S, Histiocyte Society 2001 A randomized trial of treatment for multisystem Langerhans' cell histiocytosis. J Pediatr 138:728-734

3. Geissmann F, Lepelletier Y, Fraitag S, Valladeau J, Bodemer C, Debre M, Leborgne M, Saeland S, Brousse N 2001 Differentiation of Langerhans cells in Langerhans cell histiocytosis. Blood 97:1241-1248

4. Laman JD, Leenen PJ, Annels NE, Hogendoorn PC, Egeler RM Langerhans-cell histiocytosis "insight into DC biology." Trends Immunol 2003;24:190-196
5. Fadeel B, Henter JI 2003 Langerhans-cell histiocytosis: neoplasia or unbridled inflammation? Trends Immunol 24:409-410

6. Egeler RM, Favara BE, van Meurs, M, Laman JD, Claassen E 1999 Differential In situ cytokine profiles of Langerhans-like cells and $\mathrm{T}$ cells in Langerhans cell histiocytosis: abundant expression of cytokines relevant to disease and treatment Blood 94:4195-4201

7. Egeler RM, Favara BE, Laman JD, Claassen E 2000 Abundant expression of CD40 and CD40-ligand (CD154) in paediatric Langerhans cell histiocytosis lesions. Eur J Cancer 36:2105-2110

8. Andersson By U, Tani E, Andersson U, Henter JI 2004 Tumor necrosis factor, interleukin 11 and leukemia inhibitory factor produced by Langerhans cells in Langerhans cell histiocytosis. J Pediatr Hematol Oncol 26:706-711

9. Braier J, Chantada G, Rosso D, Bernaldez P, Amaral D, Latella A, Balancini B, Masautis A, Goldberg J 1999 Langerhans cell histiocytosis: retrospective evaluation of 123 patients at a single institution. Pediatr Hematol Oncol 16:377-385

10. Bernstrand C, Cederlund K, Sandstedt B, Ahstrom L, Lundell M, Dahlquist G, Henter JI 2001 Pulmonary abnormalities at long-term follow-up of patients with Langerhans cell histiocytosis. Med Pediatr Oncol 36:459-468

11. Rosso DA, Ripoli MF, Roy A, Diez RA, Zelazko ME, Braier JL 2003 Serum levels of interleukin-1 receptor antagonist and tumor necrosis factor- $\alpha$ are elevated in children with Langerhans cell histiocytosis. J Pediatr Hematol Oncol 25:480-483

12. Henter JI, Karlen J, Calming U, Bernstrand C, Andersson U, Fadeel B 2001 Successful treatment of Langerhans'-cell histiocytosis with etanercept. N Engl J Med 345:1577-1578

13. Simonet WS, Lacey DL, Dunstan CR, Kelley M, Chang MS, Luthy R, Nguyen HQ, Wooden S, Bennett L, Boone T, Shimamoto G, DeRose M, Elliott R, Colombero A, Tan HL, Trail G, Sullivan J, Davy E, Bucay N, Renshaw-Gegg L, Hughes TM, Hill D, Pattison W, Campbell P, Sander S, Van G, Tarpley J, Derby P, Lee R, Boyle WJ 1997 Osteoprotegerin: a novel secreted protein involved in the regulation of bone density. Cell 89:309-319

14. Emery JG, McDonnell P, Burke MB, Deen KC, Lyn S, Silverman C, Dul E, Appelbaum ER, Eichman C, DiPrinzio R, Dodds RA, James IE, Rosenberg M, Lee JC, Young PR 1998 Osteoprotegerin is a receptor for the cytotoxic ligand TRAIL. J Biol Chem 273:14363-14367

15. Hayakawa Y, Screpanti V, Yagita H, Grandien A, Ljunggren HG, Smyth MJ, Chambers BJ 2004 NK cell TRAIL eliminates immature dendritic cells in vivo and limits dendritic cell vaccination efficacy. J Immunol 172:123-129

16. Yun TJ, Chaudhary PM, Shu GL, Frazer JK, Ewings MK, Schwartz SM, Pascual V, Hood LE, Clark EA 1998 OPG/FDCR-1, a TNF receptor family member, is expressed in lymphoid cells and is up-regulated by ligating CD40. J Immunol 161:6113-6121

17. Vidal K, van den Broek P, Lorget F, Donnet-Hughes A 2004 Osteoprotegerin in human milk: a potential role in the regulation of bone metabolism and immune development. Pediatr Res 55:1001-1008

18. Yun TJ, Tallquist MD, Aicher A, Rafferty KL, Marshall AJ, Moon JJ, Ewings ME, Mohaupt M, Herring SW, Clark EA 2001 Osteoprotegerin, a crucial regulator of bone metabolism, also regulates $\mathrm{B}$ cell development and function. J Immunol 166:1482-1491

19. Seidel C, Hjertner O, Abildgaard N, Heickendorff L, Hjorth M, Westin J, Nielsen JL, Hjorth-Hansen H, Waage A, Sundan A, Borset M Nordic Myeloma Study Group 2001 Serum osteoprotegerin levels are reduced in patients with multiple myeloma with lytic bone disease. Blood 98:2269-2271.

20. Croucher PI, Shipman CM, Lippitt J, Perry M, Asosingh K, Hijzen A, Brabbs AC, van Beek, EJ, Holen I, Skerry TM, Dunstan CR, Russell GR, Van Camp, B, Vanderkerken K 2001 Osteoprotegerin inhibits the development of osteolytic bone disease in multiple myeloma. Blood 98:3534-3540

21. Ziolkowska M, Kurowska M, Radzikowska A, Luszczykiewicz G, Wiland P, Dziewczopolski W, Filipowicz-Sosnowska A, Pazdur J, Szechinski J, Kowalczewski J, Rell-Bakalarska M, Maslinski W 2002 High levels of osteoprotegerin and soluble receptor activator of nuclear factor $\kappa \mathrm{B}$ ligand in serum of rheumatoid arthritis patients and their normalization after anti-tumor necrosis factor $\alpha$ treatment. Arthritis Rheum 46:1744-1753

22. Rosso DA, Roy A, Zelazko M, Braier JL 2002 Prognostic value of soluble interleukin 2 receptor levels in Langerhans cell histiocytosis. $\mathrm{Br} \mathrm{J}$ Haematol 117:54-58

23. da Costa, CE, Annels NE, Faaij CM, Forsyth RG, Hogendoorn PC, Egeler RM 2005 Presence of osteoclast-like multinucleated giant cells in the bone and nonostotic lesions of Langerhans cell histiocytosis. J Exp Med 201:687-693

24. Rolland A, Guyon L, Gill M, Cai YH, Banchereau J, McClain K, Palucka AK 2005 Increased blood myeloid dendritic cells and dendritic cell-poietins in Langerhans cell histiocytosis. J Immunol 174:3067-3071

25. Farran RP, Zaretski E, Egeler RM 2001 Treatment of Langerhans cell histiocytosis with pamidronate. J Pediatr Hematol Oncol 23:54-56

26. Arzoo K, Sadeghi S, Pullarkat V 2001 Pamidronate for bone pain from osteolytic lesions in Langerhans'cell histiocytosis. N Engl J Med 345:225-

27. Viereck V, Emons G, Lauck V, Frosch KH, Blaschke S, Grundker C, Hofbauer LC 2002 Bisphosphonates pamidronate and zoledronic acid stimulate osteoprotegerin production by primary human osteoblasts. Biochem Biophys Res Commun 291:680 686

28. Standal T, Seidel C, Hjertner O, Plesner T, Sanderson RD, Waage A, Borset M, Sundan A 2002 Osteoprotegerin is bound, internalized, and degraded by multiple myeloma cells. Blood 100:3002-3007

29. Moschen AR, Kaser A, Enrich B, Ludwiczek O, Gabriel M, Obrist P, Wolf AM, Tilg H 2005 The RANKL/OPG system is activated in inflammatory bowel disease and relates to the state of bone loss. Gut 54:479-487 
30. Bernstein CN, Sargent M, Leslie WD 2005 Serum osteoprotegerin is increased in Crohn's disease: a population-based case control study. Inflamm Bowel Dis 11:325_ 330

31. Ashcroft AJ, Cruickshank SM, Croucher PI, Perry MJ, Rollinson S, Lippitt JM, Child JA, Dunstan C, Felsburg PJ, Morgan GJ, Carding SR 2003 Colonic dendritic cells, intestinal inflammation, and $\mathrm{T}$ cell-mediated bone destruction are modulated by recombinant osteoprotegerin. Immunity 19:849-861

32. Cremer I, Dieu-Nosjean MC, Marechal S, Dezutter-Dambuyant C, Goddard S, Adams D, Winter N, Menetrier-Caux C, Sautes-Fridman C, Fridman WH, Mueller CG 2002 Long-lived immature dendritic cells mediated by TRANCE-RANK interaction. Blood 100:3646-3655

33. Rivollier A, Mazzorana M, Tebib J, Piperno M, Aitsiselmi T, Rabourdin-Combe C, Jurdic P, Servet-Delprat C 2004 Immature dendritic cell transdifferentiation into osteoclasts: a novel pathway sustained by the rheumatoid arthritis microenvironment. Blood 104:4029-4037

34. Ueland T, Bollerslev J, Godang K, Muller F, Froland SS, Aukrust P 2001 Increased serum osteoprotegerin in disorders characterized by persistent immune activation or glucocorticoid excess-possible role in bone homeostasis. Eur J Endocrinol 145:685-690
35. Franchimont N, Reenaers C, Lambert C, Belaiche J, Bours V, Malaise M, Delvenne P, Louis E 2004 Increased expression of receptor activator of NF- $\kappa \mathrm{B}$ ligand (RANKL), its receptor RANK and its decoy receptor osteoprotegerin in the colon of Crohn's disease patients. Clin Exp Immunol 138:491-498

36. Calming U, Henter JI 1998 Elevated erythrocyte sedimentation rate and thrombocytosis as possible indicators of active disease in Langerhans' cell histiocytosis. Acta Paediatr 87:1085-1087

37. Skoumal M, Kolarz G, Woloszczuk W, Hawa G, Klingler A 2004 Serum osteoprotegerin but not receptor activator of NF- $\kappa \mathrm{B}$ ligand correlates with Larsen score in rheumatoid arthritis. Ann Rheum Dis 63:216-217

38. Kannourakis G, Abbas A 1994 The role of cytokines in the pathogenesis of Langerhans cell histiocytosis. Br J Cancer 23:S37-S40

39. Kubota A, Hasegawa K, Suguro T, Koshihara Y 2004 Tumor necrosis factor- $\alpha$ promotes the expression of osteoprotegerin in rheumatoid synovial fibroblasts. J Rheumatol 31:426-435

40. Kong YY, Boyle WJ, Penninger JM 2000 Osteoprotegerin ligand: a regulator of immune responses and bone physiology. Immunol Today 21:495-502 